\title{
Cloud Point Extraction Spectrophotometric Determination of Trace Quantities of Bismuth in Urine
}

\author{
Abbas Afkhami, * Tayyebeh Madrakian and Hajar Siampour \\ Department of Chemistry, Faculty of Science, Bu-Ali Sina University, Hamadan, Iran
}

\begin{abstract}
Investigamos o processo de extração no ponto-nuvem para bismuto, a partir de soluções aquosas, usando o surfactante não-iônico Triton X-114. O método consiste na reação de complexação do Bi(III) com vermelho de bromopirogalol e extração mediada pelo sistema micelar. As condições ótimas de extração e reação $(\mathrm{pH}$, concentração de reagentes, efeito do tempo de incubação etc.) foram estudadas, e as características analíticas do método (por exemplo, limite de detecção, intervalo de linearidade) foram estabelecidas. Uma resposta linear para o íon Bi(III) foi obtida no intervalo de 4,60-120,0 $\mathrm{ng} \mathrm{mL}^{-1}$. O limite de detecção obtido foi de 2,0 $\mathrm{ng} \mathrm{mL}^{-1}$. $\mathrm{O}$ efeito da interferência de alguns ânions e cátions foi também testado. $\mathrm{O}$ método foi aplicado para a determinação de bismuto em amostras de urina humana.
\end{abstract}

A cloud point extraction process using the nonionic surfactant Triton X-114 to extract bismuth from aqueous solutions was investigated. The method is based on the complexation reaction of $\mathrm{Bi}$ (III) with bromopyrogallol red (BPR) and micelle-mediated extraction of the complex. The optimal extraction and reaction conditions (e.g., $\mathrm{pH}$, reagent concentration, effect of time) were studied, and the analytical characteristics of the method (e.g., limit of detection, linear range) were obtained. Linearity was obeyed in the range of $4.60-120.0 \mathrm{ng} \mathrm{mL}^{-1}$ of $\mathrm{Bi}$ (III) ion. The detection limit of the method was $2.0 \mathrm{ng} \mathrm{mL}^{-1}$ of $\mathrm{Bi}(\mathrm{III})$ ion. The interference effect of some anions and cations was also tested. The method was applied to the determination of bismuth in human urine sample. $\mathrm{X}-114$

Keywords: cloud point extraction, bismuth, bromopyrogallol red, spectrophotometry, triton

\section{Introduction}

Bismuth and its compound are used in semiconductors, cosmetic preparations, alloys and metallurgical additives and in the preparation and recycling of uranium nuclear fuels. ${ }^{1}$ Bismuth compounds have been used in medicine for more than 200 years in a variety of gastrointestinal disorders, because of their demulcent properties. ${ }^{2}$ It has been used in antiacids, peptic ulcer treatments, some kinds of gastritis treatments and tropical dermatological creams. As the use of bismuth in medicine increased, it has spread in the environment and the chance of exposure of organisms to bismuth has increased. A number of toxic effects in humans have been attributed to bismuth compounds, such as nephrotoxic, neurotoxic, kidney damage symptoms nephropathy, osteoarthrapathy, hepatitis and neuro-

*e-mail: afkhami@basu.ac.ir pathology. As the uses of bismuth in medicine increases, it has spread in the environment and the chance of exposure of organisms to bismuth has increased. ${ }^{3}$ Therefore, determination of bismuth at ultra-trace levels in environmental and biological samples is important.

Several methods have been developed for determination of bismuth. These include hydride generation inductivelycoupled plasma optical emission spectrometry (HG-ICPOES), ${ }^{4}$ electrothermal vaporization ICP mass spectrometry (ETV-ICP-MS), ${ }^{5}$ atomic absorption spectrometry (AAS), ${ }^{6,7}$ potentiometric stripping analysis (PSA), ${ }^{8}$ anodic stripping voltammetry $^{9,10}$ and spectrophotometry. ${ }^{11}$

However, due to the presence of bismuth in environmental and biological samples at low levels, its separation from other elements present and also the use of a preconcentration is usually necessary. Conventional solvent extraction and separation of $\mathrm{Bi}$ in the presence of co-extracting ligands, such as bis(2,4,4,-trimethyl penthyl) monothio phosphinic acid, ${ }^{12}$ pyrrolidine dithiocarbomate, ${ }^{13}$ 
has attracted considerable attention. The disadvantages of liquid-liquid extraction include the use of large volumes of organic solvents. Nevertheless, several other techniques for pre-concentration of $\mathrm{Bi}$ have been proposed, including preconcentration using $\mathrm{Mg}-\mathrm{W}$ cell electrodeposition, ${ }^{14}$ preconcentration with sodium di-n-propyl dithiophosphinate and activated carbon in a batch method, flow injection on-line two stage solvent extraction, ${ }^{15}$ flow injection on-line sorption preconcentration ${ }^{16,17}$ and solid phase extraction. ${ }^{18-22}$

When the micellar solution of a nonionic or weakly polar surfactant is heated, the surfactant changes from water soluble to oil soluble. Above a certain temperature called the cloud point, it loses its water solubility nearly completely; hence, the surfactant micelles separate out from the aqueous phase. As a result, the clear solution becomes turbid and phase separation occurs. At the cloud point, the homogeneous surfactant solution separates into two phases, with one phase (called the surfactant-rich phase) containing much of the surfactant and the other phase (called the water phase) containing mostly water and surfactant monomers at a concentration near its critical micelle concentration (CMC). The hydrophobic compounds initially present in the solution and bound to the micelles are extracted to the surfactant-rich phase, leaving only a very small portion in the water phase.

As a new separation technique, CPE offers many advantages over traditional liquid-liquid extraction. Compared with traditional solvent extraction, CPE uses water and avoids the use of large amounts of toxic and flammable organic solvents. In addition, CPE can lead to higher recovery efficiency and a large preconcentration factor because the presence of surfactant can minimize losses of analytes due to their adsorption onto the container. The other advantage of CPE is shown in the good compatibility between the surfactant and the hydro-organic mobile phase in the sample analysis using high performance liquid chromatography (HPLC). ${ }^{23}$ CPE has been used to the separation and preconcentration of metal ions in different samples prior to their determination by instrumental methods. ${ }^{24,25}$

Bromopyrogallol red [2-(2,7-dibromo-4,5,6-trihydroxy3-oxo-3H-xanthen-9-yl)benzenesulphonic acid, BPR], a metal sensitive dye, is a widely used xanthene ligand. BPR has been applied to the spectrophotometric determination of many substances, such as molybdenum, ${ }^{26}$ tin, ${ }^{27}$ cetylpyridinium chloride, ${ }^{28}$ ammonium ion ${ }^{29}$ and bismuth; ${ }^{30}$ and adsorptive anodic stripping voltammetric determination of bismuth. ${ }^{31}$

In this paper a cloud point extraction followed by spectrophotometric determination of bismuth is described. The method is based on the micell-mediated extraction of the complex of $\mathrm{Bi}^{3+}$ with BPR. A nonionic surfactant, Triton $\mathrm{X}-114$, was chosen as the extraction agent.

\section{Experimental}

\section{Apparatus}

UV-Visible absorbance spectra were recorded on a Perkin-Elmer Lambda 45 UV-Vis spectrometer spectrophotometer using $1 \mathrm{~cm}$ quartz cells $(0.5 \mathrm{~mL})$. A Metrohm $\mathrm{pH}$ meter (model 713) with a combined glass electrode was used for $\mathrm{pH}$ measurements. A water bath with a good temperature control within $\pm 1{ }^{\circ} \mathrm{C}$ and a centrifuge with $10 \mathrm{~mL}$ calibrated centrifuge tubes (Superior, Germany) were used to achieve and accelerate the phase separation process, respectively.

\section{Reagents}

All chemical reagents used were of analytical reagent grade, and triply distilled water was used for the experiments. Stock Bi(III) solution (1000 $\left.\mu \mathrm{g} \mathrm{mL}^{-1}\right)$ was prepared by dissolving $0.2312 \mathrm{~g}$ of $\mathrm{Bi}\left(\mathrm{NO}_{3}\right)_{3} \cdot 5 \mathrm{H}_{2} \mathrm{O}$ (Merck) in $3 \mathrm{~mL} 5 \mathrm{~mol} \mathrm{~L}^{-1}$ nitric acid and diluting to the mark with water in a $100 \mathrm{~mL}$ volumetric flask. Triton X-114 stock solution $(2 \% \mathrm{v} / \mathrm{v})$ was prepared by dissolving $2 \mathrm{~mL}$ of concentrated solution (Merck) in hot distilled water. A 1.8 $\times 10^{-5} \mathrm{~mol} \mathrm{~L}^{-1}$ BPR solution was prepared in water. A 0.2 mol L-1 acetic acid acetate buffer of $\mathrm{pH} 3.8$ was prepared from acetic acid and sodium acetate.

\section{Procedure}

For the cloud point extraction, an aliquot of $10 \mathrm{~mL}$ of a solution containing $\mathrm{Bi}(\mathrm{III})$ ion (10.0-100.0 $\mathrm{ng} \mathrm{mL}-1$ ), $1 \mathrm{~mL}$ of $\mathrm{pH} 3.8$ acetate buffer solution, $2 \mathrm{~mL}$ of $1.0 \times 10^{-3} \% \mathrm{BPR}$ solution and $1 \mathrm{~mL}$ of $2.0 \%$ (v/v) Triton X-114 solution, were kept for $20 \mathrm{~min}$ in the thermostatic bath at $45^{\circ} \mathrm{C}$. Separation of two phases was achieved by centrifugation for $15 \mathrm{~min}$ at $3800 \mathrm{rpm}$. The mixture was cooled in an ice bath to increase the viscosity of the surfactant-rich phase, and the aqueous phase was easily decanted by simply inverting the tube. The micellar extract from this procedure was diluted with $0.3 \mathrm{~mL}$ of methanol and transferred into a $0.5 \mathrm{~mL}$ quartz cell to measure its absorbance at $542 \mathrm{~nm}$.

\section{Determination of bismuth in urine}

The samples of urine were digested as follows. ${ }^{32}$ In a $100 \mathrm{~mL}$ beaker, $25 \mathrm{~mL}$ of urine sample accurately measured, was treated with a mixture of $5 \mathrm{~mL} \mathrm{H}_{2} \mathrm{O}_{2}$ and 
$2.5 \mathrm{~mL}$ of concentrated $\mathrm{HNO}_{3}$, and was placed on a hot plate. The sample was moderately heated up to the disappearance of the amber color. Then, the sample was evaporated almost to dryness. Thereafter, fresh portions of $2.5 \mathrm{~mL}$ of concentrated $\mathrm{HNO}_{3}$ were added to the dark residue and heated to dryness. This procedure was repeated until a white ash was obtained. Finally, the residue was dissolved in $2.5 \mathrm{~mL}$ of $3.0 \mathrm{~mol} \mathrm{~L}^{-1}$ of $\mathrm{HCl}$ and diluted to $25 \mathrm{~mL}$ with deionized water and its bismuth content was measured as described above.

\section{Results and Discussion}

Figure 1 shows the absorption spectra for BPR and its complex with $\mathrm{Bi}(\mathrm{III})$. By complexation of $\mathrm{Bi}(\mathrm{III})$ with BPR an increase in the absorbance of the solution at 542 $\mathrm{nm}$ was observed. The increase in the absorbance $(\Delta \mathrm{A})$ at $542 \mathrm{~nm}$ is proportional to the bismuth concentration. The produced complex can be extracted by CPE method. Therefore, the method is suitable for preconcentrationspectrophotometric determination of bismuth.

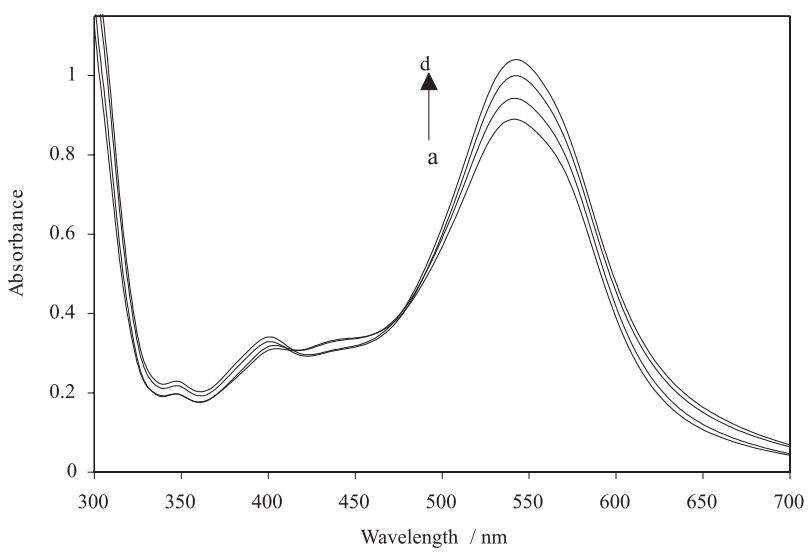

Figure 1. Absorption spectra of (a) BPR and BPR in the presence of (b) 20, (c) 45 and (d) $60 \mathrm{ng} \mathrm{mL}^{-1} \mathrm{Bi}(\mathrm{III})$ ion at $\mathrm{pH} 3.8$ in surfactant-rich phase.

\section{Optimization of the system}

To take full advantage of the procedure, the reagent concentrations and reaction conditions must be optimized. Various experimental parameters were studied in order to obtain an optimized system.

The concentration of surfactant that is used in CPE is critical factor. To obtain the optimal concentration of Triton X-114, the effect of surfactant concentration on the increase in the absorbance of the system $(\Delta \mathrm{A})$ was investigated in the range $0.04-0.22 \%(\mathrm{v} / \mathrm{v})$. As Figure 2 shows, the $\Delta \mathrm{A}$ of the solutions increased by increasing the Triton X-114 concentration up to $0.16 \%$ (v/v) and remained constant at higher concentrations. The increase in $\Delta \mathrm{A}$ by increasing surfactant concentration can be due to both more efficient extraction of the complex and medium effect. Therefore, $0.20 \%(\mathrm{v} / \mathrm{v})$ Triton X-114 was used in the proposed method.

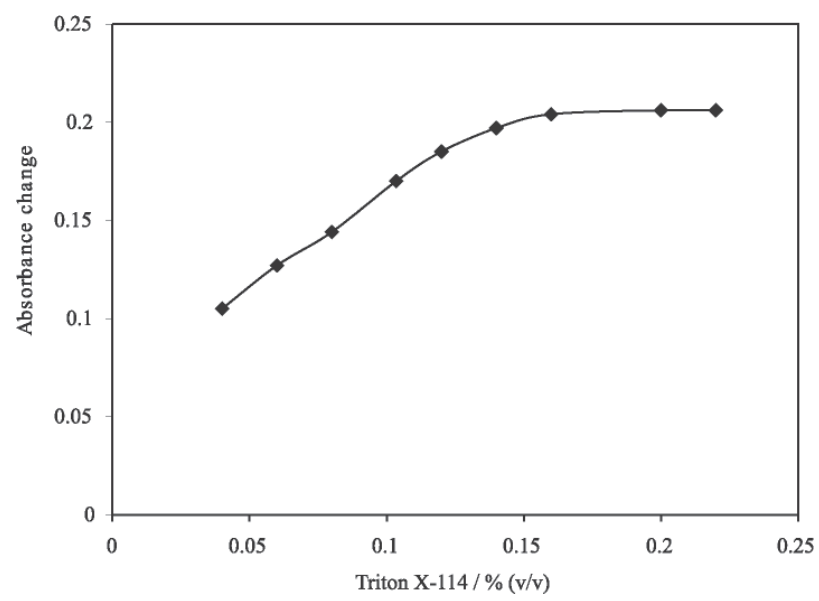

Figure 2. Effect of surfactant concentration on the CPE preconcentration performance. Conditions: $85 \mathrm{ng} \mathrm{mL}^{-1} \mathrm{Bi}$ (III) ion; $3.6 \mu \mathrm{mol} \mathrm{L}^{-1} \mathrm{BPR}$; pH 3.8 .

The complex formation reaction, the absorption spectra of BPR and the extraction efficiency are $\mathrm{pH}$ dependent. The effect of the $\mathrm{pH}$ on the $\Delta \mathrm{A}$ system was studied in the range 2-8. The $\mathrm{pH}$ of the solutions was adjusted by dilute $\mathrm{NaOH}$ and $\mathrm{HCl}$ solution using $\mathrm{pH}$ meter. The results are shown in Figure 3. As Figure 3 shows the $\Delta \mathrm{A}$ of the system increased by increasing $\mathrm{pH}$ up to 2.8 , remained constant between 2.8 and 4.5 and decreased between 4.5 and 8 . The complexation reaction at $\mathrm{pH}$ values lower than 2 and higher than 4.5 is incomplete probably due to the protonation of $\mathrm{BPR}$ and hydrolysis of $\mathrm{Bi}^{3+}$ ion, ${ }^{33}$ respectively. Therefore, an acetic acid-acetate buffer solution of $\mathrm{pH} 3.8$ was used in the proposed method.

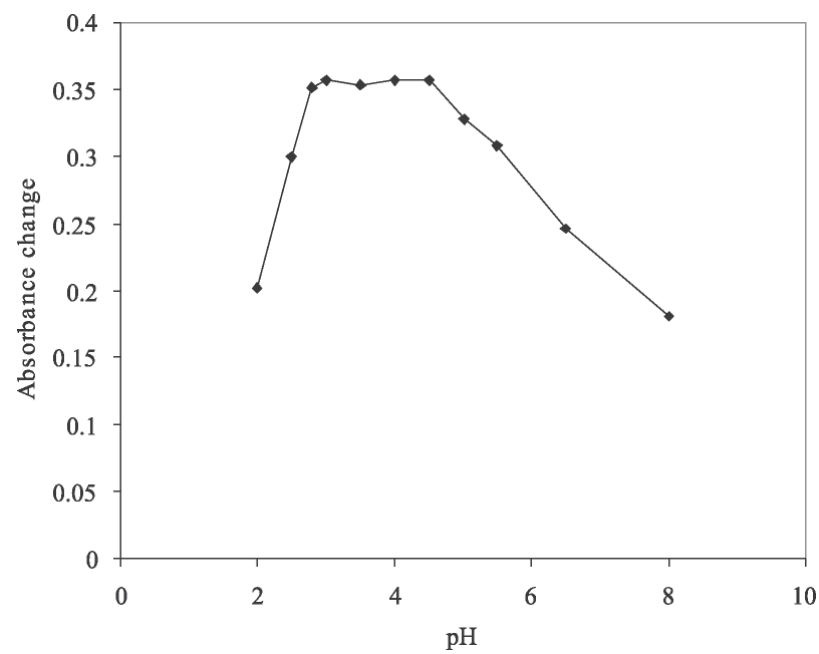

Figure 3. Effect of $\mathrm{pH}$ on the CPE preconcentration performance. Conditions: $0.2 \%(\mathrm{v} / \mathrm{v})$ Triton $\mathrm{X}-114 ; 85 \mathrm{ng} \mathrm{mL}^{-1} \mathrm{Bi}(\mathrm{III})$ ion; $3.6 \mu \mathrm{mol} \mathrm{L}^{-1} \mathrm{BPR}$. 
The effect of BPR concentration on the $\Delta \mathrm{A}$ of the system was investigated in the range $0.2-10.0 \mu \mathrm{mol} \mathrm{L}^{-1}$. The results (Figure 4) showed that the $\Delta \mathrm{A}$ of the system increased by increasing BPR concentration up to $2.0 \mu \mathrm{mol} \mathrm{L}^{-1}$ and remained nearly constant at higher concentrations. Increase in BPR concentration causes formation of more BPR-Bi complex according to Le Châtelier principle. The increase in the $\Delta \mathrm{A}$ of the solution by increasing BPR concentration is due to the increase in the concentration of complex. Constant $\triangle \mathrm{A}$ at BPR concentrations higher than $2.0 \mu \mathrm{mol}$ $\mathrm{L}^{-1}$ shows that the complex formation equilibrium does not shift significantly to right by increasing BPR concentration. Therefore, a $3.6 \mu \mathrm{mol} \mathrm{L}^{-1}$ concentration of BPR was selected as optimum.

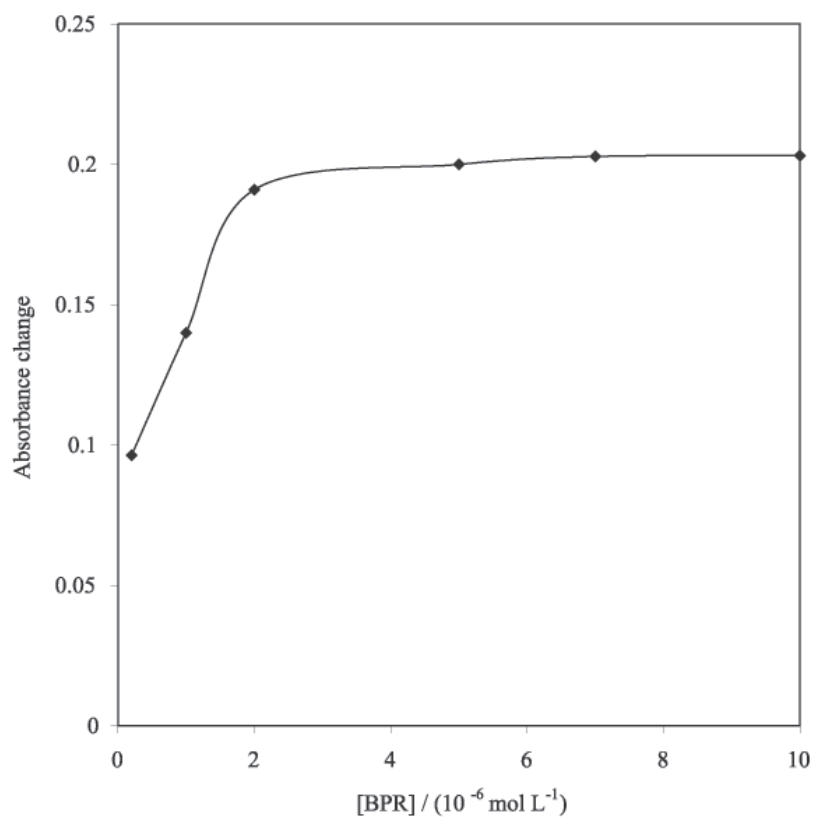

Figure 4. Effect of BPR concentration on the $\mathrm{CPE}$ preconcentration performance. Conditions: $0.2 \%(\mathrm{v} / \mathrm{v})$ Triton $\mathrm{X}-114 ; 85 \mathrm{ng} \mathrm{mL}^{-1} \mathrm{Bi}(\mathrm{III})$ ion; $\mathrm{pH} 3.8$.

The effect of equilibration temperature and incubation time was investigated. It is desirable to employ the shortest incubation time and the lowest possible equilibration temperature, which compromise efficient separation of the phases. The incubation time was kept at $20 \mathrm{~min}$, which is sufficient for the clouding procedure. It was also observed that a temperature of $45{ }^{\circ} \mathrm{C}$ is sufficient for maximum recovery of the bismuth.
As the surfactant-rich phase was very viscous, ethanol was added to the surfactant-rich phase after CPE to facilitate its transfer into spectrophotometric cell. The amount of $0.3 \mathrm{~mL}$ ethanol was chosen to have an appropriate amount of sample for transferring and measuring the sample absorbance.

\section{Analytical characteristics}

Table 1 summarizes the analytical characteristics of the optimized method, including regression equation, linear range, limit of detection, reproducibility, and preconcentration and improvement factors. The limit of detection, defined as $\mathrm{C}_{\mathrm{L}}=3 \mathrm{~S}_{\mathrm{B}} / \mathrm{m}$ (where $\mathrm{C}_{\mathrm{L}}, \mathrm{S}_{\mathrm{B}}$, and $\mathrm{m}$ are the limit of detection, standard deviation of the blank, and slope of the calibration graph, respectively), was 2.0 $\mathrm{ng} \mathrm{mL} \mathrm{m}^{-1}$. Because the amount of bismuth in $10 \mathrm{~mL}$ of sample solution is measured after preconcentration by CPE in a final volume of $0.5 \mathrm{~mL}(0.2 \mathrm{~mL}$ surfactant-rich phase $+0.3 \mathrm{~mL}$ ethanol), the solution is concentrated by a maximum factor of 20 .

In order to investigate the accuracy and reliability of the proposed method, bismuth was determined in a standard reference material (Seronorm ${ }^{\mathrm{TM}}$ trace elements urine). The concentration obtained by the proposed method $\left(25.18 \pm 0.09 \mathrm{ng} \mathrm{mL}^{-1}\right)$ was in good agreement with the indicated value of $25 \mathrm{ng} \mathrm{mL}^{-1}$.

The relative standard deviation (RSD) for six replicate measurements of $50 \mathrm{ng} \mathrm{mL}^{-1}$ bismuth was $2.41 \%$.

\section{Selectivity}

The effect of different cations and anions on the determination of $50 \mathrm{ng} \mathrm{mL}^{-1}$ bismuth ion by the proposed method was studied. An ion was considered to be an interferent when it caused an error greater than $\pm 5 \%$ in the determination of bismuth by the proposed method. The results are given in Table 2. Most of the investigated ions did not interfere in the preconcentration and determination of $\mathrm{Bi}(\mathrm{III})$ even when their concentrations were 100 to 1000 -fold excess over $\mathrm{Bi}(\mathrm{III}) . \mathrm{Fe}^{2+}, \mathrm{Fe}^{3+}$ and nitrite interfered at $50 \mathrm{ng} \mathrm{mL}^{-1}$ and $\mathrm{Sb}$ (III) interfered at $500 \mathrm{ng} \mathrm{mL}^{-1}$. The interfering effect of nitrite ion was

Table 1. Analytical features of the proposed method

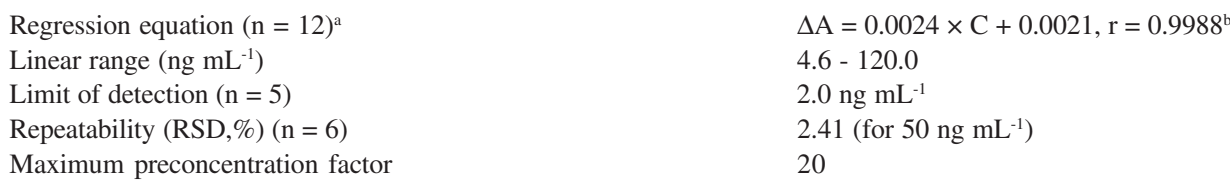

${ }^{\mathrm{a}}$ Concentration of bismuth in $\mathrm{ng} \mathrm{mL}^{-1}$. ${ }^{\mathrm{b}}$ Regression coefficient. 
Table 2. Tolerance ratio of diverse ions on the determination of $50 \mathrm{ng} \mathrm{mL} \mathrm{mi}^{-1} \mathrm{Bi}^{+3}$

\begin{tabular}{lc}
\hline Ion & Tolerance ratio $\left(\mathrm{w}_{\text {ion }} / \mathrm{w}_{\mathrm{Bi}(\mathrm{III})}\right)$ \\
\hline $\mathrm{Ag}^{+}, \mathrm{Ba}^{2+}, \mathrm{Ca}^{2+}, \mathrm{Cu}^{2+}, \mathrm{Cd}^{2+}, \mathrm{K}^{+}, \mathrm{Na}^{+}, \mathrm{Li}^{+}, \mathrm{NH}_{4}^{+}, \mathrm{CO}_{3}^{2-}, \mathrm{Br}^{-}, \mathrm{I}^{-}$, & $1000^{\mathrm{a}}$ \\
$\mathrm{Cl}^{-}, \mathrm{F}^{-}, \mathrm{SO}_{4}^{2-}, \mathrm{PO}_{4}^{3-}, \mathrm{SCN}^{-}, \mathrm{SO}_{3}^{2-}$, tartrate, $\mathrm{EDTA}$, thiourea, & \\
hydrazine, $\mathrm{NO}_{3}^{-}$ & $1000^{\mathrm{b}}$ \\
$\mathrm{NO}_{2}^{-}$ & 100 \\
$\mathrm{Mg}^{2+}, \mathrm{Pb}^{2+}, \mathrm{Ni}^{2+}, \mathrm{Co}^{2+}, \mathrm{Hg}^{2+}, \mathrm{Al}^{3+}, \mathrm{Cr}^{3+}, \mathrm{V}(\mathrm{V}), \mathrm{Mn}^{2+}, \mathrm{Sn}(\mathrm{IV})$ & 10 \\
$\mathrm{Mo}(\mathrm{V}), \mathrm{Zn}^{2+}, \mathrm{Sb}(\mathrm{III})$ & 1 \\
$\mathrm{Fe}^{2+}, \mathrm{Fe}^{3+}$ & 10 \\
\hline
\end{tabular}

${ }^{a}$ Maximum limit tested. ${ }^{\mathrm{b}}$ After removal as described in text.

Table 3. Determination of bismuth in the real samples by the proposed method

\begin{tabular}{lccc}
\hline \multirow{2}{*}{ Sample } & \multicolumn{2}{c}{ Bismuth $\left(\mathrm{ng} \mathrm{mL}^{-1}\right)$} & \multirow{2}{*}{ Recovery (\%) } \\
\cline { 2 - 3 } & Added & Found $^{\mathrm{a}}$ & \\
\hline Urine (man, & 10.0 & $9.7 \pm 0.5$ & 97.0 \\
age 28 year) & 12.0 & $12.3 \pm 1.1$ & 102.5 \\
& 15.0 & $15.5 \pm 0.7$ & 103.3 \\
\hline
\end{tabular}

${ }^{a}$ Average of four determinations \pm standard deviation.

completely removed by the addition of $1000 \mu \mathrm{g} \mathrm{mL} L^{-1}$ hydrazine to the solution before addition of BPR.

\section{Applications}

In order to evaluate the analytical applicability of the proposed method, it was applied to the determination of $\mathrm{Bi}(\mathrm{III})$ in urine samples. The percentage recoveries of spikes added to the urine samples prior to digestion are shown in Table 3. The good agreement between the results and known values indicate the successful applicability of the proposed method for the determination of bismuth in urine samples.

\section{Conclusions}

Cloud point extraction was used to the preconcentration of bismuth in different samples. The method, which is based on the cloud point extraction of the complex of bismuth with BPR, allows the determination of bismuth as low as $4.6 \mathrm{ng} \mathrm{mL}^{-1}$. The proposed method requires inexpensive instrumentation and offers good selectivity, accuracy and precision that can be applied to the determination of bismuth in real samples. The surfactant has been used for preconcentration of bismuth in samples, and thus toxic solvent extraction, has been avoided.

\section{References}

1. Thomas, D.W. In Metals and their Compounds in the Environment; Merian, E., ed., VCH: Weinheim, 1991, pp. 789801.
2. Manhart, M. D.; Rev. Infect. Dis. 1990, 12, S11.

3. Slikkerveer, A; deWolf, F. A.; Med. Toxicol. Adverse Drug Exp. 1989, 4, 303.

4. Morrow. A.; Wiltshire, G.; Huvsthous, A.; At. Spectrosc. 1997, $18,23$.

5. Hinds, M. V.; Gregorie, D. C.; Ozaki, E. A.; J. Anal. At. Spectrom. 1997, 12, 131.

6. Tokalioglu, S.; Kartal, S.; Elci, L.; Microchim. Acta 1997, 127 , 281.

7. Hall, G. E. M.; Maclaurin, A. T.; Pelchat, J. C.; Gauthier, G.; Chem. Geol. 1997, 137, 79.

8. Eskilsson, H.; Jagner, D.; Anal. Chim. Acta 1982, 138, 27.

9. Ye, R. D.; Khoo, S. B.; Electroanalysis 1997, 9, 481.

10. Wang, C. M.; Sun, Q. Y.; Li, H. L.; Electroanalysis 1997, 9, 645.

11. Abbaspour, A.; Baramekeh, L.; Talanta 2005, 65, 692.

12. Sarkar, S. G.; Dhadke, P. M.; Sep. Purif. Technol. 1999, 15, 131.

13. Lo, J. M.; Lin, Y. P.; Lin, K. S.; Anal. Sci. 1991, 7, 455.

14. Itho, S. I.; Kaneco, S.; Ohta, K.; Mizuno, T.; Anal. Chim. Acta 1999, 379, 169.

15. Wang, J.; Hansen, E. H.; Anal. Lett. 2000, 33, 2747.

16. Ivanova, E.; Yan, X. P.; Adams, F.; Anal. Chim. Acta 1997, $354,7$.

17. Giacomelli, M. B. O.; Ganzarolli, E. M.; Curtius, A.; J. Spectrochim. Acta Part B 2000, 55, 525.

18. Moyano, S.; Gasquez, J. A.; Olsina, R.; Marchevsky, E.; Martinez, L. D.; J. Anal. At. Spectrom. 1999, 14, 259.

19. Vassileva, E.; Proinova, L.; Hadjiivanov, K.; Analyst 1996, 121, 607.

20. Kocjan, R.; Garbacka, M.; Sep. Sci. Technol. 1994, 29, 799.

21. Silva, J. B. B.; Giacomelli, M. B. O.; Curtius, A. J.; Analyst 1999, 127, 1249

22. Madrakian, T.; Afkhami, A.; Esmaeili, A.; Talanta 2003, 60, 831.

23. Li, J. L.; Hung, C. B.; J. Colloid Interface Sci. 2003, 263, 625.

24. Stalikas, C. D.; TrAC, Trends Anal. Chem. 2002, 21, 343.

25. Bezerra, M. D.; Arruda, M. A. Z.; Ferreira, S. L. C.; Appl. Spectrosc. Rev. 2005, 40, 269.

26. Huang, X. R.; Zhang, W. J.; Xu, G. Y.; Han, S. H.; Li, Y.; Li, C. P.; Talanta 1998, 47, 869. 
27. Huang, X. R.; Zhang, W. J.; Han, S. H.; Wang, X. Q.; Talanta 1997, 44, 817.

28. Benamor, M.; Aguersif, N.; Draa, M. T.; J. Pharm. Biomed. Anal. 2001, 26, 151.

29. Icardo, M. C.; Torro, I. G.; Zamora, L. L.; Calatayud, J. M.; Anal. Chim. Acta 1999, 398, 311.

30. Nemcova, I.; Pesinova, H.; Suk, V.; Microchem J. 1984, 30, 27

31. Guo, H.; Li, Y.; Xiao, P; He, N.; Anal. Chim. Acta 2005, 534 143.
32. Carrero, P.; Gutiérrez, L.; Rondón, C.; Burguera, J. L.; Burguera, M.; Petit de Peña, Y.; Talanta 2004, 64, 1309.

33. Alonso, A.; Almendral, M. J.; Baez, M. D.; Porras, M. J.; Lopez Lavin, F.; Garcia de Maria, C.; Anal. Chim. Acta 2000, 408, 129.

Received: November 24, 2005 Published on the web: June 6, 2006 